\title{
A study of pattern of vitamin D deficiency in preterm and term newborns at rural teaching hospital, Haryana, India
}

\author{
Meenakshi Dadwal ${ }^{1}$, *Raghvendra Narayan ${ }^{2}$ \\ Sri Lanka Journal of Child Health, 2020; 49(3): 251-255
}

\begin{abstract}
Background: Deficiency of Vitamin D is currently the most untreated nutritional deficiency worldwide. In India, despite plenty of sunlight, VDD prevalence is $50-90 \%$ in all age groups. The neonatal vitamin D level depends wholly on the maternal vitamin $\mathrm{D}$ level because vitamin $\mathrm{D}$ crosses the placenta during the last trimester of pregnancy
\end{abstract}

Objectives: To study the pattern of VDD in preterm and term newborns delivered at M.M. Institute of Medical Sciences and Research (MMIMSR), Mullana, Haryana, India.

Method: This was a hospital-based prospective observational study. Total of 100 neonates born at MMIMSR was enrolled out of which 50 were term and 50 preterm.

Results: Out of the 100 newborns, 53 had VDD. Of the 53 newborns with VDD, $32(60 \%)$ were preterm and $21(40 \%)$ were term. Mean $25(\mathrm{OH})$ level was $21.81 \mathrm{ng} / \mathrm{dl}$.

Conclusions: In this study carried out at MMIMSR, 53\% newborns had VDD. VDD was significantly more in preterm babies compared to term babies $(\mathrm{p}<0.01)$.

http://dx.doi.org/10.4038/sljch.v49i3.9143

(Key words: Preterm, term, vitamin D, newborns, pattern)

\section{Introduction}

Vitamin D deficiency (VDD) is currently the most

${ }^{1}$ Postgraduate Resident, MM Institute of Medical Sciences and Research, Ambala, India, ${ }^{2}$ Heritage Institute of Medical Sciences, Varanasi, India

*Correspondence: drrgh1971@gmail.com<smiles>[C+]1[CH]CCC1</smiles>

orcid.org/ 0000-0001-7803-9499

(Received on 06 November 2019: Accepted after revision on 20 December 2019)

The authors declare that there are no conflicts of interest

Personal funding was used for the project.

Open Access Article published under the Creative

Commons Attribution CC-BY (c) (i) untreated nutritional deficiency worldwide ${ }^{1-3}$. In India, despite plenty of sunlight, VDD prevalence is $50-90 \%$ in all age groups ${ }^{4}$. A fetus can rarely develop rickets in utero with clinical features at birth due to severe maternal VDD ${ }^{5}$. Throughout gestation, vitamin D plays a role in the development of the skeleton, tooth enamel formation and overall fetal growth ${ }^{6}$. Further, cardiovascular risk factors can lead to VDD in neonates? ${ }^{7}$ Vitamin D is critical in the preclusion of sepsis and morbidities in the neonate ${ }^{8}$. VDD is linked to increased risk for infants developing diabetes mellitus type 1 and other endocrine disorders in later life, and atopic dermatitis at birth ${ }^{9}$. VDD is also associated with respiratory tract infections in newborns and wheezing events in later life ${ }^{10}$. Decreased vitamin D levels are considered as one of the risk factors for respiratory distress syndrome ${ }^{11}$.

Vitamin D status of pregnant mothers (20-40 years) showed that $20 \%$ of the mothers had VDD and $24 \%$ had vitamin D insufficiency ${ }^{12}$. However, maternal risk factors for having newborn with decreased vitamin D levels have not been studied very much. The neonatal vitamin D level depends wholly on the maternal vitamin D level because vitamin $\mathrm{D}$ crosses the placenta during the last trimester of pregnancy ${ }^{12}$. If the mother has VDD, less vitamin $\mathrm{D}$ will be transported across the placenta with resultant low vitamin D stores at birth. Preterm neonates are at higher risk of $\mathrm{VDD}^{13}$. Current knowledge of $25(\mathrm{OH}) \mathrm{D}$ levels at birth among preterm and term neonates is scanty.

\section{Objectives}

To study the pattern of VDD in preterm and term newborns delivered at M.M. Institute of Medical Sciences and Research (MMIMSR), Mullana, Haryana, India.

\section{Method}

A prospective observational study was conducted on 100 newborns delivered from February 2018 to August 2019 at MMIMSR. After consent was obtained, the questionnaire regarding maternal health and demographic information was collected in a pre-defined proforma. Cord blood was collected just after delivery, stored in a refrigerator and transported to the laboratory. Medical records were utilised to obtain information regarding the pregnancy and delivery, as well as anthropometric 
measurements and health of infant at birth. This information was entered into an electronic database. Standard definitions were applied regarding parity, gestation, birth weight and prematurity. Babies having major congenital anomalies, critically sick babies, babies with any pre-existing disease in mother and babies of mothers on any drug affecting vitamin D level in newborn were excluded from the study.

Cord blood samples of newborns were collected with a minimum of $2 \mathrm{ml}$ in one separate redtopped vial (with clot activator) for $25(\mathrm{OH}) \mathrm{D}$. These were sent to the biochemistry laboratory of the hospital after labelling the vials with the patient's name and internet protocol (IP) number. After allowing the blood to settle for 10-15 minutes, it was centrifuged, serum was separated and used for vitamin $\mathrm{D}$ estimation. The samples were stored at $4^{0} \mathrm{C}$ until analysed if it had to be preserved for a few days. Vitamin D levels were estimated by the chemiluminescence immunoassay (CLIA) method. The method had been fully automated, high throughput immunoassay system. The machine used was SIEMENS ADVIA Centaur ${ }^{\circledR}$ XP. Serum levels of vitamin D were classified according to severity ${ }^{14}$ :

1. Sufficient - $>30 \mathrm{ng} / \mathrm{ml}$

2. Insufficiency- $20-30 \mathrm{ng} / \mathrm{ml}$

3. Deficiency- $<20 \mathrm{ng} / \mathrm{ml}$

Statistical analysis: Data were entered into Microsoft Excel and all statistical tests were performed using Statistical Package for Social Sciences (SPSS) version 20. Categorical variables were presented as numbers and percentages. ChiSquare test was utilised to test for significance, $\mathrm{p}$ $<0.05$ being regarded as statistically significant.

Ethical issues: The study was approved by the institutional ethics committee (IEC). Informed consent was obtained from the mother/family included in the study. Data and samples were coded and stored securely.

Table 4: Relationship of vitamin D to distribution of newborns

\begin{tabular}{|l|c|c|c|c|c|c|}
\hline \multirow{2}{*}{ Group } & \multicolumn{2}{|c|}{ Vitamin D (25-OH) levels (ng/ml) } & Total & \multirow{2}{*}{$\begin{array}{c}\text { Chi square } \\
\text { value }\end{array}$} & p-value \\
\cline { 2 - 5 } & Deficiency & Insufficiency & Sufficient & & \multirow{2}{*}{12.732} & 0.002 \\
\hline Preterm & $32(60 \%)$ & $14(58 \%)$ & $04(17 \%)$ & 50 & 50 & \\
\hline Term & $21(40 \%)$ & $10(42 \%)$ & $19(83 \%)$ & 100 & & \\
\hline Total & $53(100 \%)$ & $24(100 \%)$ & $23(100 \%)$ & & & \\
\hline
\end{tabular}

Table 5 shows the relationship of gender with vitamin $D$ levels among preterm and term newborns. The differences in the gender variable of

\section{Results}

Table 1 shows the distribution of newborns into preterm and term.

Table 1

Distribution of newborns

\begin{tabular}{|l|c|}
\hline \multicolumn{1}{|c|}{ Group } & Number (\%) \\
\hline Preterm & $50(50)$ \\
\hline Term & $50(50)$ \\
\hline Total & $100(100)$ \\
\hline
\end{tabular}

Table 2 shows the distribution of newborns according to gender. The male: female ratio is 1.04:1.

Table 2

Distribution of newborns according to gender

\begin{tabular}{|l|c|}
\hline \multicolumn{1}{|c|}{ Gender } & Number (\%) \\
\hline Male & $51(51)$ \\
\hline Female & $49(49)$ \\
\hline Total & $100(100)$ \\
\hline
\end{tabular}

Table 3 shows the distribution of newborns according to vitamin D levels. In our study, the overall mean serum vitamin D level was 21.81 $\mathrm{ng} / \mathrm{dl}$ and the overall median vitamin $\mathrm{D}$ level was $19.21 \mathrm{ng} / \mathrm{dl}$.

Table 3

Distribution according to vitamin D levels

\begin{tabular}{|l|c|}
\hline \multicolumn{1}{|c|}{ Vitamin D (25-OH) level } & Number (\%) \\
\hline Sufficient & $23(23)$ \\
\hline Insufficiency & $24(24)$ \\
\hline Deficient & $53(53)$ \\
\hline Total & $100(100)$ \\
\hline
\end{tabular}

Table 4 shows the relationship of vitamin $\mathrm{D}$ to distribution of newborn. VDD was present in 53 newborns of whom $32(60 \%)$ were preterm and $21(40 \%)$ were term and the difference was statistically significant $(\mathrm{p}=0.002)$.

both the term and preterm newborns were found to be significant $(\mathrm{p}<0.05)$. 
Table 5: Relationship of gender with vitamin D levels among preterm and term newborns

\begin{tabular}{|l|c|c|c|c|c|c|}
\hline \multirow{2}{*}{ Gender } & \multicolumn{2}{|c|}{ Vitamin D (25-OH) levels (ng/ml) } & Total & $\begin{array}{c}\text { Chi square } \\
\text { value }\end{array}$ & p-value \\
\cline { 2 - 4 } & Deficiency & Insufficiency & Sufficient & & & \\
\hline Female & & & & & & \\
Preterm & $18(64.3 \%)$ & $05(50.0 \%)$ & $02(18.2 \%)$ & 25 & 6.723 & 0.035 \\
Term & $10(35.7 \%)$ & $05(50.0 \%)$ & $09(81.8 \%)$ & 24 & & \\
Total & $28(100 \%)$ & $10(100 \%)$ & $11(100 \%)$ & 49 & & \\
\hline Male & & & & & & \\
Preterm & $14(56.0 \%)$ & $09(64.3 \%)$ & $02(16.7 \%)$ & 25 & & \\
Term & $11(44.0 \%)$ & $05(35.7 \%)$ & $10(83.3 \%)$ & 26 & & \\
Total & $25(100 \%)$ & $14(100 \%)$ & $12(100 \%)$ & 51 & & \\
\hline
\end{tabular}

\section{Discussion}

Long term outcomes of VDD in the neonate include asthma, schizophrenia, multiple sclerosis, type 1 diabetes mellitus, abnormal neurocognitive outcome, and insulin resistance ${ }^{15}$. In our study of 100 newborns, 53 had VDD, 24 were vitamin D insufficient and 23 had sufficient levels of vitamin D. Of the 53 newborns with VDD, $32(60 \%)$ were preterm and $21(40 \%)$ were term. Of the 24 newborns who were vitamin $\mathrm{D}$ insufficient, 14 $(58 \%)$ were preterm and $10(42 \%)$ were term. Of the 23 newborns who had sufficient levels of vitamin D, 4 (17\%) were preterm and $19(83 \%)$ were term. The differences in vitamin D levels among preterm and term newborns were statistically significant ( $p=0.002)$.

In our study, the overall mean serum vitamin D level was $21.81 \mathrm{ng} / \mathrm{dl}$ and the overall median vitamin D level was $19.21 \mathrm{ng} / \mathrm{dl}$. In an Italian study by Cadario et $a l^{16}$, mean vitamin $\mathrm{D}$ level was $21.4 \pm 11 \mathrm{ng} / \mathrm{ml}$ in cord blood and $14.9 \pm 7 \mathrm{ng} / \mathrm{ml}$ in serum postnatally. In a Turkish study by Terek et $a l .{ }^{17}$, mean vitamin D level was $27.4 \pm 19.3 \mathrm{ng} / \mathrm{ml}$. A UK study in summer by Sulaiman et al. ${ }^{18}$ showed significantly lower serum levels in South Asian infants, compared to Caucasians. In a study by Fallahi et $a l^{19}$, mean serum vitamin $\mathrm{D}$ level in preterm infants was $13.91 \mathrm{ng} / \mathrm{ml}$. and $13.39 \mathrm{ng} / \mathrm{ml}$. in term infants.

In a study by Singh $\mathrm{G}$ et $a l^{27}$ conducted in north India, out of a total 300 cases enrolled, overall VDD was seen in $85.7 \%$. Out of total cases, $69 \%$ had levels below $20 \mathrm{ng} / \mathrm{dl}, 16.7 \%$ had insufficient levels (20-29 $\mathrm{ng} / \mathrm{dl})$ and $14.3 \%$ had sufficient levels (>30 ng/dl). Overall mean value in both groups was $18.3 \mathrm{ng} / \mathrm{dl}$. Premature newborns had low levels as compared to the term newborns. All these studies closely resemble our study results. Newborn vitamin D level depends on maternal serum level. Thus, neonates who are born to vitamin $\mathrm{D}$ insufficient mothers are at greater risk of developing $\mathrm{VDD}^{20}$. Zeghoud $\mathrm{F}$, et $a l^{21}$ found that $63.7 \%$ of neonates had calcidiol concentrations $\leq 30$ $\mathrm{nmol} / \mathrm{L}$ at birth. Fallahi et $a l^{19}$ found that $56 \%$ of newborns had a deficiency of vitamin D in Trehan.
Park S et al..$^{22}$ found that $51 \%$ of preterm babies had severe VDD $(<10 \mathrm{ng} / \mathrm{ml})$.

In our study of 100 newborns, 51 (51\%) were males with a male: female ratio of $1.04: 1$. VDD was seen in 53 newborns of whom $28(53 \%)$ were female. Insufficiency was seen in 24 newborns of whom $14(58 \%)$ were male. The gender of the newborns was not significantly linked to vitamin D levels $(p=0.657)$. Of 28 female newborns with VDD, $18(64.3 \%)$ were preterm and $10(35.7 \%)$ were term. Insufficiency was seen in 10 female newborns, of whom $5(50 \%)$ were preterm and 5 $(50 \%)$ were term. Insufficiency was seen in 14 male newborns, of whom $9(64.3 \%)$ were preterm and $5(35.7 \%)$ were term. The gender prevalence too has been reported to vary in different studies. Hameed et al. ${ }^{26}$ showed no association between vitamin D level and gender in both study groups ( $\mathrm{p}$ $>0.05$ ). A study by Gernand et al. documented that there is an interrelationship between vitamin D and placental vascular pathology differentiated by infant sex. They found dissimilarities by infant sex; mothers with high serum vitamin D level $(\geq 80$ $\mathrm{nmol} / \mathrm{L})$ were associated with a $49 \%$ reduced risk of developing a vascular pathology in the placenta in pregnancies in comparison to women with insufficient vitamin D level $(<50 \mathrm{nmol} / \mathrm{L})$ if they were pregnant by male infant and those women with normal serum vitamin D level in comparison to those with insufficient level had $44 \%$ reduced risk of placental vascular pathology (95\% confidence interval is $0.45-0.97)$. This association did not exist if women were pregnant by female infant $^{23}$. In a study by Singh G et $a l^{27}$, the majority of the newborns were male $142(68.60 \%)$ than females $81(31.40 \%)$ but the difference was statistically insignificant $(p=0.09)$. Both sexes are theoretically equally vulnerable in other studies ${ }^{24}$.

There were some limitations. Number of newborns was small, limiting our ability to see relations with these outcomes. There was no data on maternal plasma vitamin D levels during pregnancy which would have helped associate vitamin D levels in their newborns. We only analysed a single blood sample from the umbilical cord at birth which may 
not reflect vitamin D levels over time. There is also lack of follow up.

\section{Conclusions}

In this study at the M.M. Institute of Medical Sciences and Research, 53\% newborns were VDD. VDD was significantly more in preterm babies compared to term babies $(\mathrm{p}<0.01)$.

\section{References}

1. Mithal A, Wahl DA, Bonjour J-P, Burckhardt P, Dawson-Hughes B, Eisman $\mathrm{JA}$, et al. Global vitamin D status and determinants of hypovitaminosis D. Osteoporosis International 2009; 20(11):1807-20. https://doi.org/10.1007/s00198-009-09546

PMid: 19543765

2. van der Meer IM, Middelkoop BJ, Boeke AJP, Lips P. Prevalence of vitamin D deficiency among Turkish, Moroccan, Indian and sub-Sahara African populations in Europe and their countries of origin: an overview. Osteoporosis International 2011; 22(4):1009-21. https://doi.org/10.1007/s00198-010-12791

PMid: 20461360 PMCid: PMC3046351

3. Natasja M, Lips P. Worldwide vitamin D status. Best Practice and Research Clinical Endocrinology and Metabolism 2011; 25:671-80. https://doi.org/10.1016/j.beem.2011.06.00 7

PMid: 21872807

4. Harinarayan CV, Joshi SR. Vitamin D status in India-its implications and remedial measures. Journal of the Association of Physicians of India 2009; 57:40-8.

5. Hollis BW, Wagner CL. Assessment of dietary vitamin $\mathrm{D}$ requirements during pregnancy and lactation. American Journal of Clinical Nutrition 2004; 79(5):717-26.

6. Brooke OG, Brown IR, Bone CD, Carter ND, Cleeve HJ, Maxwell JD, et al. Vitamin D supplements in pregnant Asian women: effects on calcium status and fetal growth. British Medical Journal 1980; 280(6216):751-4. https://doi.org/10.1136/bmj.280.6216.751

PMid: 6989438 PMCid: PMC1600591

7. Gezmish O, Black MJ. Vitamin D deficiency in early life and the potential programming of cardiovascular disease in adulthood. Journal of Cardiovascular Translational Research 2013; 6(4):588603.

https://doi.org/10.1007/s12265-013-9475y

PMid: 23719723

8. Cetinkaya M, Cekmez F, Buyukkale G, Erener-Ercan T, Demir F, Tunc T, et al. Lower vitamin D levels are associated with increased risk of early-onset neonatal sepsis in term infants. Journal of Perinatology 2015; 35(1):39-45.

https://doi.org/10.1038/jp.2014.146

PMid: 25102323

9. Uriu-Adams JY, Obican SG, Keen CL. Vitamin D and maternal and child health: overview and implications for dietary requirements. Birth Defects Research Part C Embryo Today Reviews 2013; 99(1):2444.

https://doi.org/10.1002/bdrc.21031

PMid: 23723170

10. Pacifici GM. Effects of vitamin D in neonates and young infants. International Journal of Pediatrics 2016; 4(1):1273-85.

11. Ataseven F, Aygün C, Okuyucu A, Bedir A, Kücük Y, Kücüködük $S$. Is vitamin d deficiency a risk factor for respiratory distress syndrome? International Journal for Vitamin and Nutrition Research 2013; 83(4):232-7.

https://doi.org/10.1024/03009831/a000165 PMid: 25008013

12. Hillman LS, Haddad JG. Human perinatal vitamin D metabolism I: 25hydroxyvitamin $\mathrm{D}$ in maternal and cord blood. Journal of Pediatrics 1974; 84(5):742-9. https://doi.org/10.1016/S00223476(74)800 24-7

13. Burris HH, Van Marter LJ, McElrath TF, Tabatabai P, Litonjua AA, Weiss ST, et al. Vitamin D status among preterm and fullterm infants at birth. Pediatric Research 2014; 75(1-1):75-80. https://doi.org/10.1038/pr.2013.174 PMid: 24121425 PMCid: PMC4349515 
14. Holick MF, Binkley NC, Bischoff Ferrari HA, Gordon CM, Hanley DA, Heany RP et al. Evaluation, treatment and prevention of vitamin D deficiency: an Endocrine Society clinical practice guideline. Journal of Clinical Endocrinology and Metabolism 2011; 96(7):1911-30.

https://doi.org/10.1210/jc.2011-0385

PMid: 21646368

15. Aly H, Abdel-Hady H. Vitamin D and neonate: An update. Journal of Clinical Neonatology 2015; 4(1):1-7. https://doi.org/10.4103/2249-4847.151155

16. Cadario F, Savastio S, Pozzi E, Capelli A, Dondi E, Gatto M, et al. Vitamin D status in cord blood and newborns: ethnic differences. Italian Journal of Pediatrics 2013; 39(1):35.

https://doi.org/10.1186/1824-7288-39-35

PMid: 23735116 PMCid: PMC3685533

17. Terek D, Ozcan G, Ergin F, Koroglu OA, Yalaz M, Akisu M, et al. Vitamin D deficiency in premature infants and its side effects on neonatal prognosis. Journal of Pediatric Research 2018; 5(1):37-41. https://doi.org/10.4274/jpr.82788

18. Sulaiman RA, Sharratt CL, Lee P, Skinner A, Griffiths MJ, Webster C, et al. Ethnic differences in umbilical cord blood vitamin D and parathyroid hormone South Asians compared to Whites born in the UK. Journal of Maternal-Fetal and Neonatal Medicine 2010; 23(11):1315-17. https://doi.org/10.3109/14767051003653286 PMid: 20230314

19. Fallahi M, Afjeh A, Saneifard H, Namazi $\mathrm{N}$, Kazemian $\mathrm{M}$, Tabatabaee $\mathrm{S}$. Comparison of vitamin D level in preterm and term infant-mother pairs: a brief study. Iranian Journal of Neonatology 2016; 7(1):32-6.

20. Hollist BW, Pittard III WB. Evaluation of the total feto-maternal vitamin D relationships at term: evidence for racial differences. Journal of Clinical Endocrinology and Metabolism 1984; 59(4):652-7.

https://doi.org/10.1210/jcem-59-4-652

PMid: 6090493
21. Zeghoud F, Vervel C, Guillozo H, Walrant - Debray O, Boutignon H, Garabedian M. Subclinical vitamin D deficiency in neonates: definition and response to vitamin D supplements. American Journal of Clinical Nutrition 1997; 65(3):771-8. https://doi.org/10.1093/ajcn/65.3.771 PMid: 9062528

22. Park SH, Lee GM, Moon JE, Kim HM. Severe vitamin $\mathrm{D}$ deficiency in preterm infants: maternal and neonatal clinical features. Korean Journal of Pediatrics 2015; 58(11):427-33. https://doi.org/10.3345/kjp.2015.58.11.427

PMid: 26692878 PMCid: PMC4675923

23. Gernand AD, Bodnar LM, Klebanoff MA, Parks WT, Simhan HN. Maternal serum 25-hydroxyvitamin $\mathrm{D}$ and placental vascular pathology in a multicentre US cohort. American Journal of Clinical Nutrition 2013; 98(2):383-8. https://doi.org/10.3945/ajcn.112.055426 PMid: 23803889 PMCid: PMC3712548

24. Naik KD, Preetha R, Ramchandran AM, Nath D. Cord blood vitamin D levels of term neonates. Indian Pediatrics 2015; 52(1):75-6.

25. Hosseinzadeh Z, Kazemian M, Mashak B, Torkmandi H, Badfar G. Vitamin D status in pregnant women and their newborns in Karaj: a cross-sectional study in Iran. International Journal of Pediatrics 2018; 6(2):7117-27.

26. El Hameed A, Mohammed S, Mansour DY, Zaghla HMAA, Rishi SH. Association between vitamin D deficiency and preterm: A case control study. Egyptian Journal of Hospital Medicine 2018; 73(3):6198-205.

27. Singh G, Singh G, Brar HK, Malik S. Vitamin D levels in preterm and term neonates at birth. International Journal of Contemporary Pediatrics 2017; 48-52. https://doi.org/10.18203/23493291.ijcp201 64515 